\title{
Village Politics: Heterogeneity, Leadership And Collective Action
}

\author{
TROND VEDELD ${ }^{1}$
}

\begin{abstract}
When comparing stratified Fulani village societies, little direct relationship between the degree of heterogeneity and the success in collective action was found, except when heterogeneity among leadership and elite groups was compared. Small size and homogeneous groups do not seem to be general preconditions for stronger ability to perform collectively. First, it was found that homogeneity among elite groups enhanced capacity for collective action. Second, it was when heterogeneity in economic interests between elite groups intensified and coincided with other dimensions of heterogeneity that collective action became difficult to achieve, such as heterogeneity in economic wealth, access to land and common-pool resources, and agreement over authority of the leadership. Third, collective action was enhanced by political elites and leaders being a bit better endowed and a bit wealthier than the average community members, but not when their assets were mobilised against the economic interests and sense of fairness of other social groups. Fourth, the coordination power of the leadership related to the management of common-pool resources was undermined when leadership had extensive recourse to state officials external to the village community, underscoring the importance of autonomy.
\end{abstract}

\section{BACKGROUND}

Why do some societies succeed and others fail in collective action? Does heterogeneity hinder collective action? Beneath an apparent consensus in the common property discourse, there are several unresolved questions. Particularly important among these is the question of size and heterogeneity and their effect on collective action and resource management [Baland and Platteau, 1995; 1996; Keohane and Ostrom, 1995; Blomquist and Schlager, 1998; Uphoff, $1998] .{ }^{2}$ The main aim of this paper is to explore the conventionally held thesis that 'the smaller and more homogeneous the group the stronger its ability to perform collectively'. The paper suggests that this does not always hold, even if the thesis may be valid under certain conditions. A case study of two village-based common property regimes in Mali, controlled by Fulani agro-pastoralists, is used to inform a discussion of the effect of heterogeneity on the capability of groups for collective action related to the management of common-pool resources (CPRs). Such studies of political interaction at village level, combining quantitative household data with qualitative information, are useful to accompany wider policy studies on resource conflict, management and decentralisation [IIED, 1999].

The noble elites of Kakagnan and Dialloube villages of the Central-Northern areas of the Inland Niger Delta dominate management of some of the largest remaining floodplain pastures of West Africa, partly under village-based common-property regimes, partly under lineagebased commons (managed by customary 'masters of pasture' - the Jowro). The key dry season floodplain pastures ( $\underline{\text { bourgou }}$ ) are used in combination with rainfed pastures outside the Delta and form a CPR system of critical importance for the local and national (livestock) economy. The CPR wetlands are also of high value for floodfed rice cultivation and irrigation, both as cash crop and for food security of agro-pastoral and farming households. Herein lies a major resource conflict for collective decision-making. Should these wetlands be used as commonpool pastures (CPRs) for cows or be converted into individually held crop fields? Once converted, it is very labour demanding and difficult to return them to wetland pastures. Dilemmas need to be resolved at different levels of social organisation; from the individual household, to village and national levels. There are also significant global biodiversity interests 
attached to the conservation of these wetlands, which have been declared as environmental "hot spots" by IUCN and the World Bank [1996].

The introductory part of this paper briefly addresses the issue of group size in relation to capacity for collective action. The second part introduces the concept of 'heterogeneity', which is the main topic of the paper. Then it presents an overview of two Fulani village commons and their different histories. The third part provides a social analysis of the key user groups of CPRs, based on a household survey, and shows how various forms of heterogeneity coexist and on occasions coincide, reflecting the bargaining stands of bounded social groups. The fourth part analyses different forms of heterogeneity that exist among leadership groups of the villages and compares these with other social groups. The fifth part uses a political interaction framework in order to explain how the social groups in each village react differently to a sudden pressure emanating from the political system. The dynamics of institutional change in heterogeneous village societies is outlined, focusing on the role of coalitions of elite groups in encounters with other sub-ordinate groups in coordinating action in CPRs. Village politics matters. ${ }^{3}$ Finally, a set of theses arising from the empirical findings is presented and held up against theory on collective action.

The paper expands on views presented by Baland and Platteau [1995; 1996], who argue that although political homogeneity (a good deal of agreement about the authority structure of the CPR) and homogeneity in economic interests (common interest in use of CPRs e.g. for crop or crops) may be absolute prerequisites for collective action in a social group, homogeneity in endowments is not (equal access to CPRs). They maintain that heterogeneity will influence collective action according to the nature of its combined sources. Heterogeneity in endowments is for example held to facilitate co-operation under given conditions [cf. Ostrom, 1996; Putnam, 1993a/b; 1995; Baland and Platteau, 1995; 1996].

\section{PART 1: GROUP SIZE AND COLLECTIVE ACTION}

Regarding the issue of group size, much of the literature discussing capabilities for collective action does not keep this issue separate from issues of homogeneity/heterogeneity of the group, as noted by Baland and Platteau [1995]. It is often assumed that a small group is effective largely because it is (by definition) more homogeneous than larger groups. The two issues of size and heterogeneity need, however, to be held separate. A small community in Sahelian Africa (or elsewhere) is not necessarily particularly homogeneous. It is often an open and emergent association of actors where there are struggles and conflict and multiple directions for action and orientation in life. But there are also systems of interdependence and co-operation, meaning that social integration and differentiation are two processes that coexist, sometimes coinciding and reinforcing each other - either positively or negatively in relation to cooperative outcomes [cf. Barth, 1992:30].

My comparison of the two village regimes of Inland Niger suggests that the larger group/village has more problems in co-ordinating action in management of CPRs. Although size may be one factor which increases the problems of collective action in this particular village (Dialloube), other factors and relationships, especially those related to leadership, are more important in explanation of differential outcomes between the two villages. Those findings are supported by Ostrom, who also suggests that size is not a strong design principle for common-property regimes. She argues that 'effective leadership' can make it possible for groups to overcome problems of high group membership. Ostrom refers to her own work [1990] as well as to an overview of 21 case studies carried out by Singh and Ballabh of local 
co-operatives in India related to fisheries, forest, and water resources where the authors found that size and composition of membership did not have significant effect on co-operative performance [Keohane and Ostrom (eds), 1995:footnote 5].

\section{PART 2: HETEROGENEITY AND CAPABILITY FOR COLLECTIVE ACTION}

There is even less agreement among social scientists and economists regarding the effect of heterogeneity on the capabilities of social groups to undertake successful collective action. A review of this issue requires a clarification of the concept of 'heterogeneity' and of the sources or relations of heterogeneity that are critical for explaining patterns of interaction and collective action; here in the context of the 'caste' based Fulani society of Mali. Distinctions should be made between (a) political heterogeneity (little agreement on the legitimacy of the leaders); (b) heterogeneity in endowments (unequal access to land and CPRs); (c) in wealth/entitlements (large differences in crop production income and wealth of cattle); (d) in economic interests (diversity in the type of use of CPRs), and (e) in culture (large differences in level of education, values, life orientation). For comparison of relative success in collective action between the villages, it is important, also to distinguish between two crucial elements of collective choice-rights: i) Access-regulation (exclusion), and ii) Internal use-regulation. Access-regulation involves the right to determine who will have right of access, and how that access right may be transferred. It involves policing and enforcement of the boundaries of the common and exclusion of unwanted outsiders. Internal use-regulation concerns two issues related to management and regulation of use among insiders or co-owners of a common. First, rule making, distribution of rights, and conflict mediation. In these villages this mainly concerns regulation of the zoning of CPR pasture land versus crop land, allocation of communal and individual rights to graze, dates for entering and leaving, and rights to cultivate on individual plots, as well as conflict management (surveillance of crop fields against crop devastation). Second, co-ordination of investments in technology/infrastructure and resource enhancement, in these villages, mainly in relation to technology improvements and labour input for collective work (e.g. clearing of canals). ${ }^{4}$

\section{OVERVIEW OF TWO FULANI VILLAGE COMMONS: THE USER GROUPS}

In both villages there are several ethnic groups and 'castes' living together with distinct cultural identities that co-reside in an area with various degrees of interdependence (cooperation and competition). Dialloube has a higher population (4000 people) and possesses a larger village common than Kakagnan (2500 people). Dialloube village centre is located further from the key CPR resources. The local users of CPRs are mainly pastoralists, agropastoralists, cultivators, and agro-fishermen of different ethnic and socio-cultural background. Fulani dominate, but there are also Boso agro-fishermen, Marka and Bambara cultivators, and Twareg pastoralists. Joint political bargaining for land among social groups is typically not along lines of occupation and resource interests (cultivator/pastoralists), but according to 'caste' and lineages, the main categories being clergy, transhumantic pastoralists (former nomadic 'peul rouge'), traders, craftsmen, and Rimaybe ex-slave cultivators. ${ }^{5}$ There are also external investors in local resources with no customary rights, but close contacts with state officials and customary leaders (absentee herd owners, cash crop entrepreneurs). Both villages are surrounded by several satellite ex-slave villages and villages of agro-fishermen that formally come under their respective Village Councils. The satellite villages have long-standing rights in the CPRs, but which are being contested. Kakagnan village has expanded its village territory through heavy handed tactics, as a response to the drought (rather than restraining resource use). Its village common (harima) was approved by Sekou Amadou under Islamic law in the early 1820 s. 
FIG.1. CHARACTERISTICS OF TWO FULANI VILLAGES AND VILLAGE COMMONS

\begin{tabular}{|c|c|c|}
\hline Determinates & Kakagnan village & Dialloube village \\
\hline Population & 2500 & 4000 \\
\hline Size of common & $100 \mathrm{sq} \mathrm{km}$ & $3-400 \mathrm{sq} \mathrm{km}++$ \\
\hline Distance to CPRs & $0-3 \mathrm{~km}$ & $2-15 \mathrm{~km}$ \\
\hline Constitution of regime & Established in 1820s (Islamic law) & Established by state in $1970 \mathrm{~s}$ \\
\hline 'Caste' composition & Percentage & Percentage \\
\hline Clergy & 25 & 1 \\
\hline Transh. pastoralists & 29 & 32 \\
\hline Traders & 1 & 27 \\
\hline Craftsmen & 13 & 17 \\
\hline Cultivators (ex-slaves) & 24 & 23 \\
\hline Others (Twareg) & 8 & - \\
\hline $\begin{array}{l}\text { Political authority } \\
\text { (dominant 'castes') }\end{array}$ & $\begin{array}{l}\text { Clergy and craftsman } \\
\text { lineages }\end{array}$ & $\begin{array}{l}\text { Pastoralists ('peul rouge') and } \\
\text { lineages of traders }\end{array}$ \\
\hline Access-regulation & Strict, respected & More open, less respected \\
\hline Use-regulation & $\begin{array}{l}\text { Use-regulation in relation to } \\
\text { resource productivity }\end{array}$ & $\begin{array}{l}\text { Former use-regulation out } \\
\text { of control }\end{array}$ \\
\hline $\begin{array}{l}\text { Collective resource } \\
\text { enhancement }\end{array}$ & $\begin{array}{l}\text { Collective work organised } \\
\text { by Chief; done by ex-slaves }\end{array}$ & $\begin{array}{l}\text { Collective work organised by } \\
\text { individual smaller groups }\end{array}$ \\
\hline $\begin{array}{l}\text { i]Control of crop } \\
\text { land expansion } \\
\text { ii]Policing of CPRs } \\
\text { against outsiders }\end{array}$ & $\begin{array}{l}\text { i] Crop land allocation by Council } \\
\text { ii] Surveillance committee for } \\
\text { protection of CPRs }\end{array}$ & $\begin{array}{l}\text { i] Crop land allocation by Council } \\
\text { ii] No surveillance committee } \\
\text { for CPR protection }\end{array}$ \\
\hline $\begin{array}{l}\text { Local conflict } \\
\text { management }\end{array}$ & $\begin{array}{l}\text { Conflicts mainly resolved locally, } \\
\text { few by state }\end{array}$ & $\begin{array}{l}\text { Conflicts resolved locally, but frequent } \\
\text { recourse to state }\end{array}$ \\
\hline Graduated sanctions & Yes & Yes, but ambiguous \\
\hline Nested enterprises & $\begin{array}{l}\text { Yes, with local autonomy chosen } \\
\text { by local elite }\end{array}$ & $\begin{array}{l}\text { Yes, but less local autonomy from } \\
\text { state and external agents }\end{array}$ \\
\hline Inst. performance & Stable & Unstable \\
\hline Outcomes & $\begin{array}{l}\text { Controlled conversion of village } \\
\text { CPRs; benefits all groups }\end{array}$ & $\begin{array}{l}\text { Uncontrolled and rapid cultivation } \\
\text { of village CPRs; benefits cultivators }\end{array}$ \\
\hline
\end{tabular}

Note: The 'caste' composition is based on results from a household survey ( $\mathrm{N}=191)$, not official figures.

Source: Field data 1992-1996, Inland Niger Delta

FIG.2. DISTRIBUTION OF CATTLE-WEALTH, FIELD SIZE, AND FIELD EXPANSION (PERCENTAGE OF HOUSEHOLD HEADS)

\begin{tabular}{|lll|}
\hline $\begin{array}{l}\text { Social } \\
\text { determinates }\end{array}$ & $\begin{array}{l}\text { Percentage in } \\
\text { Kakagnan } \\
\mathbf{N = 9 1}\end{array}$ & $\begin{array}{l}\text { Percentage in } \\
\text { Dialloube } \\
\mathbf{N = 1 0 0}\end{array}$ \\
\hline Cattle-wealth & & \\
Cattle-rich & 7 & 21 \\
Medium-rich & 31 & 15 \\
Cattle-poor & 27 & 30 \\
No livestock & 34 & 34 \\
\hline Field size (average) & 3,3 hectares & 2,3 hectares \\
\hline Field expansion & 38 per cent & 33 per cent \\
last five years & expanded & expanded \\
\hline
\end{tabular}

Note: Cattle-rich household = owns 100 heads of cattle or above; medium rich = between 30 and 100 heads of cattle; cattle-poor = below 30 heads and above 1-2 heads of cattle; no cattle = less than 1-2 heads of cattle or 10 goats. The figures were developed through a wealth-ranking exercise.

Source: Field data from 1991-1993 season, Inland Niger Delta 
Dialloube's village common, however, was established only in the early 1970s with assistance of the state. Therefore its 'constitution' carries less customary legitimacy. The village centre of Dialloube embodies the local state administration and services (Arrondissement), and the key local political party offices. The centre of Kakagnan is located $15 \mathrm{~km}$ away from these politicoadministrative centres. This creates more space for autonomous decision-making and control over local resources. Fig.2. presents household data on cattle-wealth (and by implication interest in protection of grazing), field size, and rate of crop land expansion over the last five years (and by implication interest in conversion of CPR pastures to crop land). Except for the difference in distribution of 'caste' groups, and composition of 'dominant castes', the two villages are seemingly similar along most dimensions presented here. ${ }^{6}$

\section{RESOURCE ATTRIBUTES}

The resource base of the Inland Delta is complex and highly variable in relation to productivity of resources in time and space, such as pastures, crop land, fish, forest, and wildland resources. Drought is a recurrent phenomenon. The economic reasons for protecting wetland pastures and floodfed crop land around the village are several. First of all there is a critical need among the pastoral and agro-pastoral groups for maintaining milking cows in the village when the family splits during the rainy season. One part of the family migrate for seasonal grazing with the largest share of the herd for four months of the year, while a certain number of milking cows stay behind with the remaining family members. Secondly, there are multiple uses and users of the CPRs. The CPRs provide fodder for oxen, breeding space for fish, various nongrazing wild resources (grains, syrup, stalks, birds and wildlife). Since overgrazing is not a key problem, subtractible use relates to transfer of CPRs to crop land and to disputes over access to good quality arable land (flooded rice fields). At least 50 per cent of the CPRs originally set aside for grazing are now under individually held crop land or fallow land. The large size and wide differences in productivity make fencing around pastures and crop fields of the common impractical. Only in Kakagnan is there a separate Surveillance Committee for enforcing boundaries. Crop field boundaries are protected against damage by cattle according to local rules; individual cultivators are supposed to watch their fields during day time and herders the cattle at night. In practice (ex-slave) cultivators, with little say in resource conflicts, need to survey fields day and night in the cropping season.

\section{THE AUTHORITY STRUCTURE AND ITS HISTORIC ORIGIN}

The origin of the village common-property regimes can be traced back to the early 1820s (and even earlier). Following a long and dry period that started in the 1790s, a local Islamic revolution led by the clergy Sekou Amadou resulted in the formation of the Caliphate of Hamdullahi (1818-1862). Formerly nomadic Fulani settled, and increased their reliance on rice cultivation. In the zone of this study, the village common of Kakagnan was set aside for grazing for village milking cows under the control of village clergy from Amadou's clan. Gradually, larger wetland pastures were transformed into rice fields by the slave population, which consisted of conquered groups [Brown, 1969; Gallais, 1967].The 'dominant caste' coalition of Kakagnan has consisted ever since of five lineages of clergy, today with support of a powerful lineage of craftsmen (tisserands=weavers, a numerous group). This Fulani clergy elite, which encompasses the large majority of clergy in the village, combines aristocratic style with theocratic domination. It possesses symbolic power or divine rights to rule, and controls CPR resources, women and young men and their labour, as well as the labour of ex-slave cultivators through clientage. Control with labour is as important as control over land in relation to economic expansion. The representation of leaders in the Village Council is, however, a relatively balanced composition of members from these lineages, together with 
representatives of other key social groups (including the ex-slaves). The clergy- and craftsmen of Kakagnan constitute relatively small, but compact leadership and elite groups ( 25 per cent and 13 per cent of the village households respectively), both of them agro-pastoral in economic orientation. The craftsmen are led by a charismatic personality, who has survived five Village Chiefs, and who has been First Councillor since independence. Due to his strength in external relations and protection of the village CPRs, he received the honorific 'Henry Kissinger' [Vedeld, 1997]. The 'dominant caste' or power elite of Dialloube has, on the other hand, consisted mainly of the pastoralists lineage of the Chief (a large group), and two lineages of cattle-rich traders. The trader groups are 'over-represented' in the Village Council in a way perceived 'undemocratic' by local people. While the pastoralists form a numerous and not well organised group ( 32 per cent), the two lineage groups of traders are small, compact and powerful (totally 27 per cent).

Following a period of relative wealth and strength under the Hamdullahi Caliphate in the $19^{\text {th }}$ century, the pastoral Fulani gradually became more impoverished and lost control over pastures, livestock, and able bodied people under French colonial rule. ${ }^{7}$ But there were winners and losers in these processes. The French facilitated the emancipation of slaves (after 1900), more rapid introduction of oxen and ploughs (especially in the wetter 1950s and 1960s), and promoted large scale crop land expansion. Modern irrigation systems and improved market outlets led to integration in a wider economy. The local Fulani authorities were forced to respond to increasing land demands from ex-slave cultivators. The post-independence administration to a large degree continued in the path of the colonial administration and managed the Delta in the interest of the external urban society [Gallais, 1967; Moorehead, 1991; Turner, 1992; Vedeld, 1997]. The state law reconfirmed a nationalisation of all rangeland (CPRs), as introduced by the French, and established a new administrative structure, with the Village Council as the lowest level, and with the Chef d'Arrondissement and the Commandant de Cercle as the two main state representatives at district and sub-regional levels. The Village Chiefs became responsible for tax collection and village administration. At the same time, the Chief was an elected customary leader. ${ }^{8}$

In the villages of Kakagnan and Dialloube, following the authoritarian regime of Moussa Traore from 1968 and the one-Party rule (from 1979), local Fulani elites were able to establish total hegemony and control over resource regimes at the local level, including control in the Village Councils. Property rights conflicts between pastoralists and cultivators (ex-slaves) that were not resolved at village level, were referred to the (ambiguous) state administration (until 1986). The courts were corrupt. There was no real division of power between those who produced the law, those who judged according to the law, and those who enforced the law. In practice, the Fulani noble elite in both villages, as long as it played on the side of the state and the Party, controlled all channels for voicing claims beyond the village level; the political Party, the administrative, the legal, and customary channels. This concentration of power in the Chief and his allies obviously restricted individual as well as collective freedom, and formed a lid on social movements and political engagement by wider social groups. Political and economic organisation at local level was forbidden by state law, and discouraged by the Fulani elite. In both villages, the CPRs were governed in an authoritarian way, in part by use of customary means, in part by support of state military police, which was requested from the local or regional state officials (through close personal or political alliances and bribes). The military police assisted the Council in surveillance of the boundaries of the commons. Suppression took place of less influential groups (ex-slaves, non-Fulani), and there was increasing conflict and tension over access to land, both internally and with external groups (e.g. ex-slaves and 
cultivators from neighbouring Boso and Marka villages, paid herders of absentee cattle owners in urban areas).

A sudden change process was initiated in 1991, when the two village- and CPR- regimes came under external pressure from the political system in the form of a national Coup d'état. The process of institutional change that followed will be further explained in Part 5. of the paper. By this stage, resource decline, following 30 years of drought, had weakened the local economy, undermined leadership capacities, and led to social disintegration through high migration rates. With the introduction of multi-partism, a new political situation emerged locally, with several political parties and new opportunities for heterogeneous groups to organise and place demands on the authority structures. The outcome was rather immediate changes in property rights institutions. In Dialloube, the CPR regime was rapidly destabilised with negative effects on the resource base. In Kakagnan, a new more 'democratic' regime was established.

\section{EFFECTS ON RESOURCES AND MANAGEMENT}

The uncontrolled transformation of the floodplain resource-system to crop land, as observed in Dialloube, had negative effects on pastures and the livestock economy, on wild resources and bio-diversity. It had negative spill-over effects on the fisheries that depend on the wetlands. Satellite imagery shows that Dialloube CPRs are more exposed to crop land fallow and crop encroachment than those of Kakagnan. Even so, the negative ecological effects are likely to be more an effect of drought and change in flood levels, than direct impacts of human activities (as 95 per cent of local respondents claim and which is supported by research; Turner [1992]; ORSTOM [1994]; Vedeld [1997]). Furthermore, a balanced conversion of the floodplains to crop land, as found in Kakagnan, can be defended for food and livelihood security reasons. In situations where the flood-level becomes too low for the wetland grasses (bourgou) to grow, conversion of CPRs to rice is a rational response. The change from a cultural landscape of floodplain pastures to one of crop fields is not always to the detriment of the ecology.

\section{PART 3: SOCIAL ANALYSIS OF HETEROGENEOUS GROUPS}

Below, a social analysis of inter- and intra-community conditions is presented, in order to understand the bargaining stands in property rights disputes across villages, comparing heterogeneity along different dimensions for diverse bounded social groups. An interesting picture emerges from the analysis, which is based on a household survey $(\mathrm{N}=191)$, in part confirming the findings of historic and interpretative observations, in part enriching it.

\section{POLITICAL HETEROGENEITY (AGREEMENT ABOUT AUTHORITY)}

Rarely does one find completely decentralised systems of interaction among groups of coowners in CPRs. In most situations, as among the Fulani, there exists some form of central authority with responsibilities for creating, maintaining and enforcing rights and rules for the use of CPRs. This type of authority can be more or less representative and more or less legitimate in the way it has recourse to external authorities or reflects rules, values and norms shared by different groups of the community. Such third party authority typically forms an integral and important part of the combined property rights regime. ${ }^{9}$ As maintained by Baland and Platteau there is 'abundant evidence to show that the economic elite' of society largely bears the costs of initiating and performing regulatory tasks of the property regimes [1995:19; 1996]. There is, however, no direct connection between power and wealth for example among the clergy of Kakagnan, who are both powerful and influential in the management of the CPRs, while being only medium-rich to poor. ${ }^{10}$ Now, how to compare political heterogeneity across 
groups and villages if wealth cannot alone be used as a good proxy variable? Baland and Platteau make a distinction between heterogeneity in economic wealth (endowment/ entitlements) and political dimensions of heterogeneity. Baland and Platteau here take homogeneity in political dimensions to mean that in the user group concerned there is a good deal of agreement about the authority structure; about the way it makes rules, allocates and enforces rights. 'Heterogeneity' therefore describes circumstances in which there is limited support for the authority structure [Baland and Platteau, 1995:20].

In order to assess the degree of consensus about the leadership in various capacities, household heads were asked to rank their views about the performance of the Chief and the 'Master of pasture' (Jowro) in two key functions that are important determinants of their legitimacy and customary power; access control to crop land (land allocation); and tenure conflict management. ${ }^{11}$

\section{FIG.3. HETEROGENEITY IN VIEWS ABOUT LOCAL LEADERSHIP}

\begin{tabular}{|lllll|}
\hline $\begin{array}{l}\text { Social status } \\
\text { group }\end{array}$ & $\begin{array}{l}\text { Percentage of households that } \\
\text { view the Chief as 'very strong' in } \\
\text { regulating access control to land }\end{array}$ & $\begin{array}{l}\text { Percentage of households that } \\
\text { view the Jowro as 'very strong' in } \\
\text { regulating access control to land }\end{array}$ \\
Village Councillors & $\begin{array}{l}\text { Kakagnan } \\
\text { Clergy }\end{array}$ & Dialloube & Kakagnan & Dialloube \\
Pastoralists & 46 & 7 & 57 & 100 \\
Traders & 46 & - & - & - \\
Craftsmen & - & 16 & 79 & 100 \\
Cultivators & 42 & 4 & - & 94 \\
\hline
\end{tabular}

Note: The percentages refer to the relative number of household heads perceiving the Chief vs. the 'Master of pasture' (Jowro) as 'very strong' versus 'strong', 'not so strong', 'negligible' in access control to land $[\mathrm{N}=191]$. The Jowro is the key customary leader for CPR-management outside the village commons. Source: Field data 1992-1993, Inland Niger Delta

Let me concentrate on differences in views across villages and 'caste' groups and focus on difference between leadership groups and sub-ordinate resource users. In Kakagnan, in answer to a direct question, all Village Councillors responded that they view their Chief as 'very strong' in controlling access to crop land (compared to 'strong', 'not so strong', 'negligible') (Fig. 3.). Access to new crop land is typically at the expense of CPR pastures. Among the two other leadership groups, the clergy and the craftsmen, 46 per cent and 42 per cent respectively share this view. Among the ex-slaves 41 per cent have this opinion. In Dialloube, only seven per cent of the Village Councillors, four per cent of the traders, and 16 per cent of the transhumantic pastoralists perceive their Chief as 'very strong' in allocation of land. None among the group of ex-slave cultivators believes the Chief is 'very strong' in access-control. Hence, low legitimacy is reflected both among leaders and subordinate groups. In contrast, as many as 80 per cent among all respondents find the customary 'masters of pasture' - the Jowro - to be 'very strong' in controlling access to land. This view is largely shared by both leadership groups and sub-ordinates. It is important here that the same pattern repeats itself for the respondents' views about the role of the Chief and the Jowro in tenure conflict resolution [cf. Vedeld, 1997:251]. The difference in views about the Chief and the Jowro, reflects a respect for the Jowro as customary leader, and that the Jowro seldom has recourse to state officials in land management matters. 
The problem of opportunistic leaders' having recourse to the local state officials in resolution of internal disputes, as often done in Dialloube, is compounded by local state officials' frequent encouragement of such contacts and their being only too willing to respond. This undermines autonomy and legitimacy in decision-making, and fosters rentseeking. ${ }^{12}$ Following conflicts over cultivation in the CPRs in 1990 and 1991, the state representative, the Commandant de Cercle, in April 1992 united the conflicting parties for a village meeting, which agreed to protect five CPR zones from cultivation. But realising that this decision worked against their vested interests in cultivating, members of the ruling elite/Councillors later approached the Commandant, and 'convinced' him to change this decision, and to include only two zones for protection; which happened to be the two zones in which the majority of the ex-slaves cultivated [cf. Declaration no. 16 CM, Mopti 2 Nov., 1992]. The ex-slaves refused to accept the new ruling, one of their leaders arguing: 'Why did the letter have another conclusion than the meeting?' 'On a grasse la pâte' ${ }^{13}$ 'Until they cut our heads we will continue to cultivate!'. People's distrust of the state administration is highest in Dialloube, where none views the state as playing a 'very positive' role in tenure conflict resolution. But views differ. As expected following this event, the two groups that are most negative to the functioning of the state administration are the cultivators and traders of Dialloube; only seven per cent and eight per cent of whom respectively, believe the state is doing a 'positive' job in this respect. ${ }^{14}$ In contrast, among the pastoral group of Dialloube as many as 75 per cent believe the state is doing a positive job. Among all groups in both villages, $90 \%$ claim they 'never' or 'seldom' obtain any benefits from the work of the state administration [Vedeld 1997:252; 1998].

\section{HETEROGENEITY IN ENDOWMENTS (ACCESS TO CPRS AND CROP LAND)}

Baland and Platteau provide several examples where homogeneity in endowments (understood as access to CPRs) co-exists with large politico-cultural heterogeneity in village societies: in Japan [Mckean, 1992a/b], in 'caste' dominated villages of India [Bardhan, 1993a/b], as well as in most pastoral societies of Africa [Shanmugaratnam et al., 1992; Lane, 1998].

\section{FIG.4. HETEROGENEITY IN POLITICAL POWER, ENDOWMENTS AND ENTITLEMENTS ACCORDING TO STATUS GROUP IN KAKAGNAN (K) AND DIALLOUBE (K)}

\begin{tabular}{|lllllll|}
\hline & \multicolumn{2}{c|}{ Endowments } & \multicolumn{3}{c|}{ Entitlements } \\
\hline $\begin{array}{l}\text { Social } \\
\text { status } \\
\text { group }\end{array}$ & $\begin{array}{l}\text { Political } \\
\text { power }\end{array}$ & $\begin{array}{l}\text { Size of } \\
\text { crop field } \\
\text { (ha) }\end{array}$ & $\begin{array}{l}\text { Tenure } \\
\text { security } \\
\text { (percentage } \\
\text { households w. } \\
\text { all fields in } \\
\text { vill. common) }\end{array}$ & $\begin{array}{l}\text { Investments } \\
\text { (percentage } \\
\text { households } \\
\text { with one } \\
\text { work-oxen } \\
\text { or more) }\end{array}$ & $\begin{array}{l}\text { Crop income } \\
\text { (estimated } \\
\text { value in } \\
\text { Franc CFA) }\end{array}$ & $\begin{array}{l}\text { Cattle wealth } \\
\text { (percentage } \\
\text { households } \\
\text { with above } \\
\text { 100 heads } \\
\text { of cattle) }\end{array}$ \\
\hline V. Council. & high & 3,1 ha & 87 & 47 & 60000 & 33 \\
Clergy & K: high & 1,7 ha & 76 & 28 & 24000 & 4 \\
Pastoralists & D: high & 0,5 ha & 84 & 10 & 30000 & 14 \\
Traders & D: high & 2,2 ha & 96 & 43 & 102000 & 46 \\
Craftsmen & K: high & 1,8 ha & 70 & 17 & 66000 & 10 \\
Cultivators & low & 7,2 ha & 56 & 70 & 117000 & 0 \\
\hline
\end{tabular}

Note: Crop income is an estimated value combining subsistence production and sales over two seasons in Kakagnan (K) (1991/92) and three seasons in Dialloube (D) (1991/92/93).

Source: Field data 1992-1993, Inland Niger Delta

All groups have relatively egalitarian access to CPRs, while poor groups have little access to private land and power. In Fulani society, the opposite is in fact the case; there is fairly egalitarian access to private crop land (ex-slaves have acquired the largest fields), while 
access to CPR grazing is more exclusively for the noble elite and influential Fulani. Regarding access to crop land, the 'caste' to which people belong seems to be the main determinant of the size of crop fields, the cultivators (ex-slaves) having by far the largest arable land (7,2 hectares). ${ }^{15}$ The transhumantic pastoralists have only small fields $(0,5$ hectares). Among the leadership groups, the Village Councillors and traders of Dialloube have the largest fields (3,3 hectares and 2,2 hectares). Both groups control indirectly even larger land areas through patron client relations (ex-slaves cultivating for them). Both groups have their fields almost exclusively within the boundaries of the village common. Exslaves have only an indirect access right to grazing in the common, through conferring livestock to the clergy or pastoralists. Regarding the large fields of the ex-slaves, it is important that rights in the CPRs are typically defined through a combination of ascribed rights (according to status/'caste') and according to political negotiation and achievements. What matters in terms of actual use and benefits of the resources is not only endowments (access- and use-rights), but also capabilities to transform endowments into entitlements (benefit streams) [Dreze and Sen, 1990]. Such capabilities are related to control over capital, labour, technology (oxen), livestock, skills and market access, not only to statically defined 'rights' to land. Only by actually having livestock, can a CPR endowment be transferred into a benefit stream for the household.

\section{HETEROGENEITY IN ENTITLEMENTS (CATTLE WEALTH/CROP INCOME)}

The social group with the highest presence of cattle rich families is that of the politically powerful traders of Dialloube, with 46 per cent cattle-rich (above 100 head of cattle) (Fig. 4.). Some of them have more than a thousand head of cattle. In contrast to the cattle-rich traders is the group of powerful but poor clergy of Kakagnan, among whom only four per cent are considered cattle-rich. Hence, power and wealth do not coincide for this group. It is interesting, however, that the four other social groups with high representation among the cattle-rich, are all powerful leadership groups; the Village Councillors, the transhumantic pastoralists of Dialloube, and the craftsmen of Kakagnan (with 33 per cent, 25 per cent, and 25 per cent representation of cattle rich respectively). Crop income, on the other hand, is highest among the cultivators (ex-slaves). It is smallest among clergy and pastoralists.

\section{HETEROGENEITY IN ECONOMIC INTERESTS (USE OF CPRs)}

Heterogeneity in economic interests is recognised as a key constraint to collective action [Baland and Platteau, 1995; 1996]. It also turns out so in this context, but in a different manner than often suggested.

FIG.5. HETEROGENEITY IN ECONOMIC INTEREST IN USE OF CPRS (PERCENTAGE OF HOUSEHOLD HEADS ACCORDING TO RECORDED LAND USE SYSTEM)

\begin{tabular}{|lllllllll|}
\hline Social group & \multicolumn{2}{c}{ Pastoralism } & \multicolumn{2}{c}{ Agro-pastoralism } & \multicolumn{2}{c|}{ Cultivation } & \multicolumn{2}{c|}{ Non-land income } \\
& K & D & K & D & K & D & K & D \\
\hline Village Council & 57 & 0 & 14 & 50 & 14 & 17 & 14 & 33 \\
Clergy & 16 & n.a. & 24 & n.a. & 24 & n.a. & 36 & n.a. \\
Pastoralists & 89 & 91 & 0 & 3 & 0 & 0 & 12 & 6 \\
Traders & n.a. & 7 & n.a. & 25 & n.a. & 11 & n.a. & 57 \\
Craftsmen & 8 & 0 & 42 & 24 & 8 & 6 & 42 & 71 \\
Cultivators & 0 & 0 & 0 & 4 & 100 & 87 & 0 & 9 \\
\hline
\end{tabular}

Note: Kakagnan village $=\mathrm{K}$, Dialloube village $=\mathrm{D}$

Source: Field data 1991-1993, Inland Niger Delta 
There are many case studies of pastoralists and farmers in conflict over the use of CPRs for crops or cows in Africa (although there are also interdependencies, cf. Hussein [1998]; IIED [1999]). The peculiarity of the context in these villages is perhaps that resource use conflict is in part internalised to the community, in part even to each household. ${ }^{16}$ Looking at the overview for all groups, the households interviewed are spread fairly equally between pastoralism and cultivation as the most important economic interest in use of CPRs (30 per cent each). A more illuminating picture emerges when looking at the different social groups broken down by village (Fig.5.). The shaded boxes are of particular significance, since they represent forces that are for 'protection of pastures'. The group of transhumantic pastoralists is the largest group among all and the only group clearly in favour of protecting pastures. The traders are mainly agro-pastoral in orientation, yet it is also the group with most cattle-rich members (with large income from sales of cattle as middlemen). It is particularly interesting that the group of Village Councillors of Kakagnan is basically pastoral in economic orientation, while those of Dialloube are agro-pastoral (since most of them are traders).

\section{HETEROGENEITY IN VIEWS, VALUES AND EDUCATION}

It should be accepted that differences in views, which relate to knowledge and information, affect choice in resource management and capacity to agree on collective action, whether or not they coincide with heterogeneity in power, status or economic interests. The household survey shows, first of all, that among all groups CPR degradation is considered as "very important' by a large majority of the households, except among the cultivators (ex-slaves) of Dialloube. In Kakagnan, even the group of cultivators share views with the others about the importance of degradation. All groups attribute the degradation mainly to drought and low flood (about 95 per cent). Secondly, there are significant differences in views about what constitutes the key management problem between the social groups in each of the villages. As a reflection of the historic and geographic localisation of the village common of Kakagnan, squeezed between 'hostile' neighbours, the users of CPRs are concerned with the access-regulation issue i.e. the problem of keeping outsiders from poaching grass in the common (illegally or with unofficial agreement of corrupt local leaders). ${ }^{17}$ Few of the households interviewed in Kakagnan are concerned about the internal use-regulation, if comparison is made with Dialloube, where this is people's preoccupation. Here, 72 per cent and 61 per cent among the transhumantic pastoralists and traders respectively (leadership groups), think that cultivation of the CPRs is a 'very important' problem. None of the cultivators interviewed thinks so [Vedeld, 1997]. Regarding heterogeneity in cultural values and education the most visible difference between social categories is between the two leadership groups of Dialloube. While 29 per cent of the traders have more than seven years of education, only six per cent of the pastoralists have; while 21 per cent of the traders command French, only nine per cent of the pastoralists do; while 60 per cent of the traders have been migrants to urban areas for five years or more, only six per cent of the pastoralists have had this experience. The length of migration expresses exposures to urban and 'modern' values, new skills, and life orientation. Such differences clearly compound communication problems between the two groups. The Village Councillors, a majority being traders (Dialloube) or clergy (Kakagnan), possess similar leadership qualities, such as higher education and more exposure to outside world. ${ }^{18}$

\section{PART 4: HETEROGENEITY AMONG LEADERSHIP GROUPS}

As suggested by Baland and Platteau [1995; 1996] it is often not clear in the social science literature what is meant by 'heterogeneity' when it is argued that it works against collective 
action (or when it is claimed that homogeneity favours). It may be particularly important to distinguish between political heterogeneity, heterogeneity in endowments, entitlements (wealth) and in economic interests (here: in use of CPRs). Often inequalities in wealth alone receive the whole blame for collective action failures, even in cases when heterogeneity in economic interests (or political aspects) may be the main issue. How can a comparison of the conditions of heterogeneity/homogeneity between social groups in the two villages contribute to explanation of differential responses to the co-ordination problems in the management of CPRs?

\section{HETEROGENEITY AMONG LEADERSHIP AND ELITE GROUPS}

When all social groups are compared, each of these Fulani villages faces great and fairly similar types of heterogeneity in economic interests, endowment, wealth, political legitimacy and cultural positions. Hence, one would expect that both villages faced similar problems in collective action, if homogeneity was a strong precondition. How to explain that one village regime succeeds where the other fails? The social analysis becomes more illuminating if a comparison is made between the leadership groups of the two villages. It turns out that while the leadership groups of Kakagnan are fairly homogeneous along most dimensions, those of Dialloube, in contrast, are heterogeneous along most dimensions. This can be characterised as in Fig. 6.

As will be further explained below, in a situation of increased political pressure, the two leadership groups of Kakagnan (the clergy and the craftsmen) were able to agree among themselves about the authority structure (political homogeneity). Reflecting their common economic interest as agro-pastoral groups, the two leadership groups also agreed on the need for pursuing a balanced conversion of CPR grazing to crop land. None of the leadership groups had sufficient capital or interest to start any large-scale crop cultivation at the expense of other groups' interest in CPR grazing. Both groups had fairly equal access to CPRs/crop land (homogenous endowments), differences in cattle-wealth and crop land income were not so large (homogenous in wealth), they had common views about the management problem facing the CPR regime and how to address it, and were not too different culturally (culturally homogenous).

\section{FIG.6. DEGREE OF HETEROGENEITY IN LEADERSHIP VERSUS ALL VILLAGE GROUPS}

\begin{tabular}{|lllll|}
\hline Sources of & \multicolumn{2}{c|}{ Kakagnan village } & \multicolumn{2}{c|}{ Dialloube village } \\
heterogeneity & Leadership & All villagers & Leadership & All villagers \\
Political (legitimacy) & $*$ & $* * *$ & $* * *$ & $* * *$ \\
Endowment & $*$ & $* *$ & $* *$ & $* * *$ \\
Cattle wealth & $* *$ & $* * *$ & $* * *$ & $* * *$ \\
Crop land income & $*$ & $* * *$ & $* * *$ & $* * *$ \\
Economic interest & $*$ & $* *$ & $* * *$ & $* * *$ \\
Problem perception & $*$ & $* *$ & $*$ & $* *$ \\
\hline
\end{tabular}

Note: The leadership or political elite groups are defined as the Village Councillors in combination with clergy and craftsmen in Kakagnan and with transhumantic pastoralists and traders in Dialloube.

The stars denotes high [***], medium [**], low degree of heterogeneity [*] between these leadership groups compared to heterogeneity when comparing all groups.

Source: Social analysis of field data 1992-1996, Inland Niger Delta

In Dialloube, on the other hand, it is particularly striking that the two leadership groups, the traders and the pastoralists, had different economic interests in the use of the CPRs. In a situation of drought and declining income from livestock, the traders decided to take 
advantage of a new political context and mobilise their larger capital possessions for expansion of cash-crop fields in the floodplains (enhancing further heterogeneity in endowments and entitlements). Hence, conflicts intensified with the pastoralists and their demand for preservation of key grazing zones. The two leadership groups were not in agreement about the authority structure (political heterogeneous), and the traders used their power to overrule the Chief and to gain access to CPRs. The coordination and governance problems were compounded by large cultural heterogeneity.

A thesis can therefore be put forward that the degree of heterogeneity among political elite groups is more important for capacity to perform collectively than heterogeneity among all social groups.

\section{PART 5: HETEROGENEITY AND INSTITUTIONAL CHANGE}

But as illustrated below, it is not the static conditions of 'community' or 'heterogeneity' that matter most, but rather the dynamics of patterns of interaction over time, reflecting how various forms of heterogeneity intensify and coincide and create motives for action among influential groups. The institutional change processes in Kakagnan and Dialloube villages, respectively, reflect contrasting patterns of interaction when the one-Party regime fell at national level in Mali in 1991.

\section{INSTITUTIONAL CHANGE IN KAKAGNAN}

Kakagnan village is at this point in time dominated by the political elite of medium-rich, well-educated and organised clergy, in alliance with cattle-rich and powerful craftsmen. As explained, this political elite shared economic interests in the use of CPRs (both are basically agro-pastoral). In the change process that followed the national events, the young clergy, inspired by the student movement in the capital, were especially active and engaged. They demanded 'democratic' changes and influence in the CPR regime. The political elite in position, guided by the craftsman 'Henry Kissinger', made timely political concessions in order to maintain a political consensus about the leadership related to resource management. Key members among the clergy in political opposition and among the young clergy gained access to offices in the Village Council and the CPR Surveillance Committee. The two elite groups continued to have an economic interest in a balanced conversion of CPRs to crop land, meaning that important floodplain pastures remained protected. This interest represented a 'compromise' between the interests of the two large sub-ordinate groups of the village, the cultivators (ex-slaves) and the pastoralists. The former group was interested in conversion of CPRs to crop land, while the latter in conserving the CPRs for pastures. The two elite groups did not have economic capacity (wealth) to expand crop land at the expense of CPRs beyond what was seen as 'fair' by the sub-ordinate groups. For such expansion they needed capital to invest in oxen, ploughs, and labour. The craftsmen had no ambition of taking over the political leadership from the Chief, who was a member of the clergy. They did not trigger access conflicts and cultural antagonies of the sort that emerge in Dialloube. Despite large heterogeneity among social groups in the village, the political elite could assume leadership and provide an authority structure necessary for enforcement of rules and conflict resolution. An important additional dimension was that all social groups agreed on the need for strong access regulation and policing against intruders from outside villages, reflecting the CPRs' location between other powerful villages. The outcome in Kakagnan was foremost a change in the access-regulation of the CPR regime. Institutional change was the result as much of pressures emanating from within the village political system, as from outside forces. The process was pushed forward by groups of 
young clergy. The agricultural entrepreneurs (craftsmen and ex-slaves) as well as the pastoralists accepted the old order, and did not challenge the new authority structure, whose policy did not mean much change in access to resources for them. Many of them sought new fields outside the village common. No real change in social relations has occurred between elites and sub-ordinates. The women were politically active in the process, but within culturally defined limits [Vedeld, 1997].

\section{INSTITUTIONAL CHANGE IN DIALLOUBE}

In Dialloube, in contrast, the Chief and the Village Council did not come to terms on a new regime structure, with rather dramatic results for the management of the CPRs. Following a local power vacuum that emerged as the one-Party state fell, both traders and ex-slave groups 'rushed' to the protected zones with their oxen and ploughs, and started a rapid and disordered conversion of large CPR zones to crop land. How can this be explained? The political elite of Dialloube consisted of a weakly organised and rich (as well as many poor) members of the Chief's pastoralist lineage, and groups of cattle-rich and well-organised traders. While the pastoral elite had little economic or cultural interest in cultivation, the traders had over the last decades increasingly used their wealth to expand their land for cash-cropping, due to a livestock economy on decline as a result of long-term drought. This reflected their market- and profit orientation. The Village Council had until recently controlled the conversion of CPRs, partly due to the Chief having frequent recourse to the state and the one-Party system. The one-Party state officials supported a policy of denying ex-slaves access to CPRs in manners perceived as unfair (see above). This policy was an 'easy way out' for the Chief, who was under constant threat from the two powerful groups of traders while in need of support to withstand the pressure for arable land from ex-slaves. But it undermined the Chief's legitimacy as leader. When the one-Party system fell, the traders, who dominated the Village Council, saw an opportunity to expand cash-cropping in the CPRs further. The Chief was not capable of re-establishing a viable political coalition among his own pastoral group. He was outmanoeuvred in politics by the better organised and compact elite groups of traders. The large cultural differences between the traders and the pastoralists enhanced communication and co-ordination problems (differences in values and education). There was no politically engaged associations of young men among the pastoral groups which could counter the factional rivalries. The ex-slaves, who before the fall of the one-Party, had been arrested on two occasions for cultivation of CPRs, were now able to establish coalitions with the traders and members of the dominant political party (ADEMA) in the capital, and gain support of the Governor of Mopti at regional level. The ex-slaves started voting for ADEMA. The traders - constituting noble groups of fairly high rank - did in this process challenge the authority of the Chief and signalled that they might take over the Chieftainship (if the situation allowed). The Chief has lost much of his power and legitimacy in the process. This was also because he earlier supported land grabbing by Village Councillors in certain pastures, which an open village meeting had decided should be protected as pastures (with support of local state officials). Hence, the Chief and the Council corrupted their own decisions. Today, the Chief has no central position in any of the local political parties. He is also old and tired of fighting, as he says himself (after being in position since 1968, and functioned as Chef de Canton under the French). The outcome in Dialloube affected mainly internal use-regulation. Traders and ex-slaves no longer accepted to refrain from use of CPRs. Change was due to a combination of two sorts of pressures; one emanating from the external political system, that induced internal political reaction; and the other emanating from the economic system, related to the integration of traders and trader associations in the larger market. The result was a minor internal 
revolution with changes in power structures and social relations as many of the ex-slaves left former pastoralist patrons. Some of them attached to new patrons among the traders, either through new patron-client relationships or as paid agricultural labourers. This may be good for the ex-slaves, but potentially bad for the environment (loss of wetland and biodiversity).

\section{THEORY, DISCUSSION AND CONCLUSION}

The empirical findings lead to the following set of general theses, which contribute to an explanation for why one village failed (Dialloube) where the other succeeded in collective action (Kakagnan), despite both being composed of fairly heterogeneous groups and operating under comparable external circumstances.

Homogeneity among leadership and elite groups enhances capacity for collective action in a social group. An heterogeneous community is capable of finding solutions to collective action dilemmas, as long as there is reasonable degree of homogeneity among the leadership groups. Heterogeneity does not generally hinder collective action.

This is particularly illustrated in Kakagnan village, where the society and its leaders show ingenious ways and means of overcoming problems created by its heterogeneous groups. This suggests:

Small size and homogeneous groups are not general preconditions for stronger ability to perform collectively in stratified village societies.

The relative success in creating a new CPR regime in Kakagnan, as well as the problems in doing so in Dialloube, suggests that:

In stratified village societies with a narrow participation in political decision-making, the degree and form of heterogeneity among the political elite critically affects capacity for collective action. This capacity is conditioned by the history and differential experience of the elite groups, individual leadership capabilities, and processes of interaction and rivalry between the elite, broader community groups, and external agents, such as state officials.

Capacity for collective action is particularly undermined when heterogeneity in economic interests between elite groups intensifies, and coincides with political, endowment, entitlement and cultural heterogeneity.

It is when the traders start expanding crop land and intensify economic interest conflicts with groups of pastoralists and cultivators, that the CPR regime becomes destabilised. The traders also hold a strategic position (in the Village Council), which enable them to dispose of the corporate arrangement for CPR management and restraint in use. In this situation, various forms of heterogeneity start coinciding in ways perceived negative by several groups. This implies that the heterogeneity issue must be contextualised, made conditional, and studied as a dynamic process related to changes in social relationships [Douglas, 1986:48]. If heterogeneity in various forms coincides and intensifies, and if conflict and competition increase beyond culturally acceptable levels, especially as perceived by elite groups and other influential groups, then collective action is likely to suffer. The static conditions of heterogeneity/ homogeneity within the community do not adequately explain differences in cooperative capability, however. This leads to the next thesis. 
In village-based commons, where the authority structure is closely associated with the lowest level in the state apparatus, it is critical how leaders and elites choose to have recourse to external authorities in collective management, and to what extent this recourse is perceived legitimate among influential groups. Explanation for collective action requires analysis of the dynamic interactions at the encounters at the interface between internal and external processes and relationships [cf. Long, 1989].

Political homogeneity, understood as a good deal of agreement about the authority structure, is an essential prerequisite for collective action in a social group. Capacity for collective action is undermined when low legitimacy of leaders in decision-making is compensated for by extensive recourse to rent-seeking state agents external to the community and heavy handed tactics. A certain autonomy in local decision-making is essential. Factional and personal rivalry and favouritism of non-economic character influence outcomes of political bargaining.

By comparing the accepted leadership role of the clergy in Kakagnan and the controversial role of the traders in Dialloube, it can be maintained that:

Collective action is enhanced by political elites and leaders being a bit better endowed (more CPRs/land) and a bit wealthier (more cattle) than the average community members, since larger asset owners are likely to benefit more and be willing to take on extra burdens in maintenance and enforcement of the regime (as suggested in Mancur Olson's thesis regarding provisions of public goods:1965). But collective action is hindered if assets are mobilised against the economic interests and sense of fairness of other influential groups.

The role of the clergy as leaders in Kakagnan further illustrates that:

Leaders also take on extra tasks of enforcing rules and regulations without direct compensation in purely economic terms, and they perceive a variety of motives for being leaders. ${ }^{19}$

A leader of a village CPR regime, whose concern is both to organise the village and to convince the government to assist in enforcing the regime, faces several dilemmas. First, he needs to balance his own vested interests and the community interests in the use of the CPRs. In economic terms, one might agree that if the leader is a small landowner or cattleowner, he will benefit only marginally from his own efforts. On the other hand, if he is a large land- or cattle-owner, he will benefit substantially. He may then risk the possibility that other community members see his efforts as a means of promoting his own interests, rather than as a contribution to common benefits. In this case, it would be difficult to persuade other community members to contribute by refraining from use of CPRs, enforcing boundaries, or otherwise providing labour to joint investments (cf. Baker cited in Magrath [1989]). Secondly, he must choose from which sources he wants to build his authority; from 'below' (Kakagnan) or from 'above' (Dialloube), and from which groups within the society; from among his own family and kinfolk (Dialloube), or from broader societal groups (Kakagnan).

A certain political stratification and cultural ('caste') heterogeneity is conducive to collective action, since people accept local authority and conform to status, even if it may 
work against their economic interests. If political stratification and cultural differences are tantamount to differences in economic interests, or otherwise raise cultural antagonies, collective action is hindered.

Heterogeneity in economic interests can foster coordination in CPR management, but only under certain limited conditions, such as when different forms of specialisation in use among multiple users lead to complementarity in the use of CPRs and/or exchange of products and factors for production (e.g. labour).

It is also obvious from Kakagnan that:

Generational and gender differences and interactional relationships matter. The younger generation of men, as well as women, can play a critical role in re-orientation of authority structures and institutions.

The paper suggests that as long as there is reasonable homogeneity among elite groups, cooperative outcomes can be relatively persistent even among heterogeneous social groups. 'Homogeneity' conditions for a social group as a whole are perhaps not as important as often maintained. ${ }^{20}$ The findings underscore Ostrom's key point that leaders are essential for monitoring and enforcement of CPR regimes, and that the issue of collective action largely revolves around 'what it means to have recourse to external authorities' [Ostrom, 1992:348]. It is a fact that the state and state officials are often central actors in local resource regimes (cf. Berge, [1998]; Berge and Stenseth (eds), [1998]). A main weakness in the literature dealing with conditions for collective action is that too much explanatory weight is often placed on 'homogeneity' and endogenous conditions of a social group alone (cf. Ostrom [1992] commenting on Singleton and Taylor [1992:316]). ${ }^{21}$ In the cases presented here, the outcome of internal bargaining and decision-making is to a large extent determined in the encounters at the interface between endogenous and exogenous processes; between local and external political agents and arrangements. In order to explain the politico-institutional change processes it is necessary to assess conditions within each of the bounded social groups of the village ('inter-community' conditions), as well as the ties and relationships that bridge between these bounded groups of different kinds ('intracommunity' conditions) and between community groups and external agents and arrangements ('extra-community' conditions). In Kakagnan, the coordination power of the elite is such that that heterogeneity in economic interests is bridged between bounded groups of different kinds. In Dialloube, on the other hand, this is not the case.

In a broad sense, the empirical findings of the paper support Baland and Platteau, who argue that there is a need to distinguish between various forms of heterogeneity in analysis and explanation of collective action [1995; 1996], especially in relation to heterogeneity in endowments, entitlements (wealth), and economic interests. They also maintain that political homogeneity and homogeneity in economic interests may be absolute prerequisites for collective action in a social group, while homogeneity in endowments is not. On three key issues, the paper represents a modification of Baland and Platteau. First, it proposes that more prominence be given to heterogeneity conditions among leadership groups and the supply processes in explanation of village groups capacity for collective action. If you want to study the capacity of the poor and subordinates for collective action, study the elite. Secondly, the encounters at the interface between endogenous and exogenous processes and relationships is a critical arena for understanding leadership and the social fabric that create capacity for 
collective action. Among Fulani, the supply of effective leadership comes in response to active engagement by young men and women, traders' associations, and networks of subordinate groups (ex-slaves) that bargain for improved rights and assets, as well as from demand placed on the leaders from the state. The motives for bargaining within each of the bounded groups arise from a combination of internal and external relationships, such as individual demand for new land (technologically induced through adoption of ox-ploughing and need for more crop land for each household), demand for improved relative prices, or through diffusion of new values and ideas about 'good governance' from the outside world. Thirdly, it is not the static conditions of 'heterogeneity' that matter most for capacity to perform collectively, whether among the elite or broader groups, but rather the dynamics of patterns of interaction between stakeholders to CPRs of the given social context. The dynamic interaction reflects how various forms of heterogeneity intensify and coincide and create motives for action among influential groups. This means that the heterogeneity issue should be contextualised and studied in an historic perspective. This places more weight in the explanation of collective action on authority, rules, networks, and learning, and less on resources and exchange processes related to entrepreneurial response to relative price changes in markets as often maintained in neoinstitutional economics and conventional property rights theory. ${ }^{22}$

There are many forces that shape a village property regime beyond those defining collective action dilemmas discussed here. Drought and ecological variability are independent factors leading to decline in local household economies and reduced capacity for coordinated action and supply of leadership. The infrastructural constraints and weakly developed access to external markets undermine communication and technological development. Access to laboursaving technology (e.g. oxen and plough) is often a more important constraint to household livelihood security than access to land. Education and health facilities are poor, restricting human resources development. Solutions to these collective action problems require 'comanagement arrangements' and external financial and organisational support of a more enabling and committed development state than found in Mali today. The strengthening of community-based resource regimes does not necessarily require much in terms of external financial input. But it does require ingenious national leaders who can foster policies and law guided by genuine dialogue, not by domination and manipulation. Only active dialogue can nurture more transparent village politics and civic engagement necessary to form accountable leadership and inclusive institutions for collective action.

\footnotetext{
${ }^{1}$ The paper has been re-worked from the defence lecture for the doctoral scientiarum thesis held $9^{\text {th }}$ December 1997 at the Department of Land Use Planning, Agricultural University of Norway. The empirical data were collected over a five year period (1991-1996) among agro-pastoral Fulani communities of the Inland Niger Delta. The author wishes to thank Boubacar Ba and Salmana Cisse for valuable assistance with field-work, and Erling Berge, Espen Sjaastad and one anonymous reviewer for helpful comments.

${ }^{22}$ See also the wider literature on CPR regimes: Ostrom [1992; 1995; 1997]; Singleton and Taylor [1992]; Bromley [1992]; Hackett [1992]; Hackett et al. [1994; 1995]; Young [1995]; Alston, Eggertson, North (eds) [1996]; Hanna et al. [1996]; Mearns [1996]; Meinzen-Dick and Jackson [1996]; Edwards and Stein [1998; 1998b]; Leach, Mearns, Scoones, [1998].

${ }^{3}$ Politics is here defined as competition for power among interest groups and influence on decisions with effects on coordinated action in the management of CPRs. The CPR literature has mainly been concerned with politics as a coordination problem (i.e. qualities of the governance process) and less with issues of power.

${ }^{4}$ But it also involves broader aspects of providing infrastructural development (rural roads, market access, social services), as well as maintaining belief systems and social structures.
} 
${ }^{5}$ The 'caste system' divides the whole society into a large number of hereditary groups, distinguished by separation in matters of marriage and contact, in division of labour; and finally hierarchy, which ranks the groups as relatively superior or inferior to one another cf. definition of 'caste' by C. Bouglé in Dumont [1970:21]. There is no notion of 'untouchables' like in the Indian caste system.

${ }^{6}$ The concept 'dominant caste' is here used as a broad category to describe the locally recognised leadership and elite groups of the village. While the household data distinguish between individuals with leadership positions (e.g. Village Councillors) and those without such positions, they do not distinguish between those key lineages and individuals within the 'dominant caste' with most power ('the power elite') from those lineage groups and individuals with less power.

7 The relative decline in the political economy of the Muslim Fulani societies of Mali relates to wider system changes, such as decline of the lucrative Trans-Saharan trade and culture, following the fall of Baghdad to the Mongols, and discovery of a sea-borne trade route around Africa. This gradually marginalised the Sahelian Fulani in world trade, and reduced cultural impulses from the Arabic world. Internal conflicts, corruption of rulers and brutality of successive conquerors were also probable causes of decline [Brown, 1969; Branndel, 1979; Lippman, 1990:76; Webb, 1995].

${ }^{8}$ Following the path of the past, recourse to the local state representative, the Chef d'Arrondissement, became common among the Chiefs in CPR conflict management, reinforcing the legal status of the Village Council as the lowest level in the state apparatus, rather than as a representative local government and body for the users of CPRs.

${ }^{9}$ Property rights allocate power, wealth and status between different groups of society and are determined through social relations at different levels of society [Bromley, 1992; North, 1990, Eggertson, 1990; Alston, Eggertson, North, 1996].

${ }^{10}$ Reflecting their cultural interest in Islam, maraboutism, and intellectual activities, the clergy of Kakagnan have well below average land endowments in the village common (field size 1,7 hectares), low income from crop cultivation (Fcfa 24000 per year) and are relatively cattle-poor (only four per cent among them are cattle-rich). Lack of direct relations between who contributes and who gains in the management of the CPRs regimes reflect the fact that power and status mediate decision-making, social relations and distribution of benefits from resource use. Discussions with leaders confirm a set of motives for their willingness to supply extra input in enforcement of the CPRs (e.g. genealogical obligations, gains in symbolic power and status, as well as economic wealth-seeking). Broader behavioural motives are generally accepted outside neo-classical economic theory, [Scott, 1995; Bromley, 1989; Douglas, 1986; Hodgson, 1988;, 1991; [ed] 1993; Keesing, 1981].

${ }^{11}$ One may argue that opinions on whether or not leaders are 'very strong' in access control to land is not an adequate test of leadership legitimacy. An ineffective leader in access control may, in theory, still be a legitimate leader. In the concrete context, however, given that land tenure conflicts constitute the key political issue, the way such conflicts are perceived and handled, strongly reflects views on the legitimacy of the leaders. Interviews with local informants confirm this.

12 The nested character and legal status of village-based resource regimes actually put the local leaders and Chiefs under an impossible cross-pressure between personal, communal and external state interests. The village leaders often identify as much with state officials as with representative leaders of the CPR users.

13 'Someone has 'buttered' the cake'.

${ }^{14}$ It is important that many of the ex-slaves work as tenants or under clientage for trader families.

${ }^{15}$ The cultivators of Kakagnan have the least secure tenure rights, indicated by the fact that only 18 per cent among them have all field plots within the boundaries of the village common. It is still the group with highest investment in crop cultivation ( 86 per cent of household heads with one or more plough oxen). Most of them have been forced, however, to cultivate at least one or more plots of land in a zone $20-30 \mathrm{~km}$ away from the village, in the region of Kootiya under land controlled by the Jowro (customary 'master of pasture').

${ }^{16}$ Most households are engaged in both crop cultivation and herding and therefore need to decide how to allocate land and household labour and capital resources between crop cultivation and herding.

${ }^{17}$ When the village common of Kakagnan was established in the 1820 s, very fertile arable land and floodplain pastures were taken away from neighbouring villages and nomadic pastoral groups, including Dialloube, and some of these groups still challenge the boundaries of the common.

${ }^{18}$ Compared to average for all household heads in the sample, the Village Councillors have higher education (27 percent completed primary education against average of 6 percent), better command of 
French (27 percent against average of 19 percent), more exposure to outside world (33 percent have been migrants to urban areas five years or more against average of 18 percent, and they are slightly younger (48,5 years against average of 52 years).

${ }^{19}$ Robert Wade [1988; 1992] in his studies of irrigation systems in 'caste' based villages of SouthIndia, suggests that the effectiveness of the local Councils in irrigation control depends on the councillors' all having substantial private interest in seeing that the control works, and the interest is greater a larger a person's landholding. This 'economic approach' to explanation of collective action, as found in neo-institutional economics, assumes that there is always such a direct connection between a persons wealth/access and political position/influence, as in Mancur Olson's initial thesis [Olson, 1965; Hardin 1968; Wade, 1988; Eggertson, 1990; North, 1990; 1991; 1993; Alston, Eggertson, North, 1996; Eggertson in Hanna et al., 1996]. Political heterogeneity is assumed to be symmetrical to heterogeneity in wealth (in order to be able to maintain economic modelling of society, Bromley, [1989]), which is not always the case here, where power and status mediate such relations.

${ }^{20}$ Ostrom for example maintains that even if 'community' is not necessary (but facilitating) for initial negotiations around resolution of a CPR problem, it is necessary in order to sustain a robust CPR regime over time [Ostrom, 1992]. Ostrom modifies her view slightly in later works [Keohane and Ostrom, 1995].

${ }^{21}$ While in reality the village community and the state are both relatively open, permeable and interacting organisations that mutually reinforce or weaken each other's influence on the CPR regimes (often on unequal terms). Coordination power in both organisations are generated partly inside, partly outside the organisation itself, reflecting historic relationships. Incentives for coordinated action among individuals and groups at local level are affected by macro-policies and law as enforced by the state [Edwards and Stein, 1998; 1998b].

${ }^{22}$ Goldsmith [1995]; Putnam 1993a]; Scott [1995]; Vedeld [1997]; Baland and Platteau [1995; 1996]. 


\section{REFERENCES}

Alston, L J., Eggertson, T., and D. C. North (eds.), 1996, Empirical Studies in Institutional Change, New York: Cambridge University Press

Baland, J. M. and J. P. Platteau, 1995, 'Does Heterogeneity Hinder Collective Action?' Cahiers de la Faculte des Sciences Economoques Sociales no. 142, Namur, Belgium, Facultes des Sciences Economiques et Sociales, Facultes Universitaires Notre-Dame de la Paix

Baland, J. M. and J. P. Platteau, 1996, Halting Degradation of Natural Resources. Is there a Role for Rural Communities? Oxford: FAO/Clarendon Press

Bardhan, P., 1993a, 'Symposium on Management of Local Commons', Journal of Economic Perspectives, vol.7 (4):87-92

Bardhan, P., 1993b,' Analytics of the Institutions of Informal Cooperation in Rural Development', World Development vol 21 (4):633-639

Barth, F., 1992, 'Towards Greater Naturalism in Conceptualizing Societies', in A. Kuper (ed.) 1992: Conceptualizing Society, London: Routledge, pp17-33

Berge, E., 1992, 'Unintended Consequences and the Planning of Welfare', Paper presented to the 6th AESOP Congress, Stockholm, 3-6 June

Berge, E., 1998,'Some Observations on the Modelling of Human Impact on Renewable Resources', Paper presented at the $7^{\text {th }}$ IASCP Conference, Crossing Boundaries, June 10-14, 1998, Vancouver, Canada

Berge, E. and N. Chr. Stenseth (eds), 1998, Law and the Governance of Renewable Resources. Studies from Northern Europe and Africa, San Francisco: ICS Press

Blomquist, W. and E. Schlager, 1998, 'Individual and Institutional Heterogeneity and the Resolution of CPR Dilemmas', Paper presented to IASCP $7^{\text {th }}$ Conference, Crossing Boundaries, June 10-14, Vancouver

Branndell, F., 1979, Civilization and Capitalism 15th-18th Century III. The Perspectives of the World. London: Fontana, 1984

Bromley, D., 1989, Economic Interests and Institutions. The Conceptual Foundation of Public Policy, New York: Basil Blackwell

Bromley, D. (ed), 1992, Making the Commons Work, Theory, Practice and Policy, San Francisco: ICS Press

Brown, W. A., 1969, The Caliphate of Hamdullahi ca. 1818-1864. A Study in African History and Tradition, $\mathrm{PhD}$ in History, University of Wisconsin, University Microfilms

Douglas, M., 1986,_How Institutions Think, London: Routledge and Kegan Paul

Drèze J. and Sen A., 1990, The Political Economy of Hunger. vol. 1. Entitlement and Well-Being, Oxford/New York: Clarendon Press

Dumont, L., 1970, Homo Hierarchicus, The Caste System and its Implications, London: Weidenfield and Nicolson

Edwards, M. and N. A. Stein, 1998, 'Developing an Analytical Framework for Multi-Use Commons', Journal of Theoretical Politics 10(3):337-383

Edwards, M. and N. A. Stein, 1998b, 'Defining and Anlysing the Role of Contextual Factors in Common Property Resource Management', Paper presented to IASCP $7^{\text {th }}$ Conference, June 10-14, Vancouver

Eggertsson, T., 1990, Economic Behaviour and Institutions, Cambridge: Cambridge University Press

Gallais, J. 1967: Le Delta Interieur du Niger: Étude de géographie régionale, Mémoires de l'Institut Fondamental d'Afrique Noir, no 79, IFAN, Dakar, Vol I et II

Goldsmith, A. A., 1995, 'Democracy, Property Rights and Economic Growth', Journal of Development Studies 32 (2):157-174

Hackett, S. C., 1992, 'Heterogeneity and the Provision of Governance for Common-Pool Resources', Journal of Theoretical Politics, vol. 4 [3], July: 325-342

Hackett, S., Dudley, D. and J.M. Walker, 1994, 'The Role of Communication in Resolving Commons Dilemmas: Experimental Evidence with Heterogenous Appropriators', Journal of Environmental Economics and Management 27, 99-126

Hackett, S., Dudley, D. and J.M. Walker, 1995, 'Heterogeneities, Information and Conflict Resolution: Experimental Evidence on Sharing Contracts', in Keohane, R. O. and E. Ostrom (eds.), 1995, Local Commons and Global Interdependence, Heterogeneity and Cooperation in Two Domains, London: SAGE Publications

Hanna, S., C. Folke, and K.G. Maler, 1996, Rights to Nature, Washington, D.C.: Island Press

Hardin, G., 1968,' The Tragedy of the Commons', Science 162, 1243-1248 
Hodgson, G. M., 1988, Economics and Institutions: A Manifesto for a Modern Institutional Economics, Cambridge and Philadelphia: Polity Press and University of Pennsylvania Press

Hodgson, G. M., 1991, 'Institutional Economic Theory: The Old Versus the New', in G. M. Hodgeson: After Marx and Sraffa, Essays in Political Economy, London: Macmillan

Hodgson, G. M. [ed], 1993, The Economics of Institutions, Brookfield: Edward Elgar Publishing, Reference collection: including by Hodgson: 'Introduction' and 'Institutional Economics: Surveying the 'Old' and the 'New', Metroeconomica 44:1, Basil Blackwell:001-028

Hussein, K., 1998, 'Conflict Between Farmers and Herders in the Semi-Arid Sahel and East Africa: A Review', London: ODG/DEV/IIED

IIED, 1999, Land Tenure and Resource Access in West Africa: Issues and Opportunities for the Next Twenty Five Years, IIED Drylands Programme, IIED: London

Keesing, R. M., 1981, Cultural Anthropology, A Contemporary Perspective (second edition), London: Holt, Rinehart and Winston, Saunders College Publishing

Keohane, R. O. and Ostrom, E. (eds), 1995, Local Commons and Global Interdependence, Heterogeneity and Cooperation in Two Domains, London: SAGE Publications

Lane, C., 1998, Custodians of the Commons: Pastoral Land Tenure in East and West Africa, London: Earthscan

Leach, M., Mearns, R., and I. Scoones, 1998, 'The Institutional Dynamics of Community-Based Natural Resource Management: An Entitlement Approach', Paper presented to IASCP $7^{\text {th }}$ Conference, June 1014, Vancouver

Lippman. T. W., 1990, Understanding Islam, An Introduction to the Muslim World (revised edition), New York: Mentor Book, Penguin

Long, N., 1989, Encounters at the Interface, A Perspective on Social Discontinuities in Rural Development, Wageningen Sociologische Studies, Wageningen Agricultural University

Magrath, W. B., 1989, The Challenge of the Commons: The Allocation of Nonexclusive Resources, Washington D.C: World Bank

McKean, M., 1992a, 'Success on the Commons. A Comparative Examination of Institutions for Common Property Resource Management', Journal of Theoretical Politics 4(3):247-281

McKean, M., 1992b, 'Management of Traditional Common Lands (Iriachi) in Japan', in Bromley, D. (ed.) 1992, Making the Commons Work, Theory, Practice and Policy, San Francisco: ICS Press

Mearns, R., 1996, 'Community, Collective Action and Common Grazing: the Case of Post-Socialist Mongolia', Journal of Development Studies 32 (3):297-339

Meinzen-Dick, R. and L. A. Jackson, 1996, 'Multiple Uses, Multiple Users of Water Resources', IFPRI, IASCP Conference, June 5-9, Berkeley

Moorehead, R., 1991, Structural Chaos: Community and State Management of Common Property in Mali, Thesis for D Phil. in Development Studies, University of Sussex

North, D., 1990, Institutions, Institutional Change and Economic Performance, Cambridge University Press

North, D., 1991, Institutions, Journal of Economic Perspectives, (1):97-112

North, D., 1993, 'Towards a Theory of Institutional Change', in Barnett, W.A., Hinich, M.J. and N.J. Schofield (eds.) 1993: Political Economy: Institutions, Competition, and Representation, New York: Cambridge University Press

Olson, M., 1965, The Logic of Collective Action: Public Goods and the Theory of Groups, Cambridge (MA), Harvard University Press

ORSTOM, 1994, La Pêche dans le Delta Central du Niger, Approche Pluridisciplinaire d'un Système de Production Haliéutique, Paris: ORSTOM/Karthala/IER

Ostrom, E., 1990, Governing the Commons, the Evolution of Institutions for Collective Action, Indiana University, Cambridge: Cambridge University Press

Ostrom, E., 1992, 'Community and the Endogenous Solution of Commons Problems', Journal of Theoretical Politics vol 4 (3): 343-353

Ostrom, E., 1995, 'Constituting Social Capital and Collective Action', in Keohane, R.O. and E. Ostrom (eds.) 1995, Local Commons and Global Interdependence, Heterogeneity and Cooperation in Two Domains, London: SAGE Publications

Ostrom, E., 1997, 'Self-Governance of Common-Pool Resources', (to appear in Peter Newman (ed.): The New Palgrave Dictionary of Economics and Law (forthcoming), Workshop in Political Theory and Policy Analysis, Indiana: Indiana University, Bloomington

Ostrom, E., Walker, J., and R. Gardner, 1992, 'Covenants with and without a Sword: Self-Governance is Possible', American Political Science Review vol 86(2):404-417

Putnam, R. D., 1993a, Making Democracy Work: Civic Traditions in Modern Italy, Princeton Univ. Press 
Putnam, R.D., 1993b, 'The Prosperous Community. Social Capital and Public Life', The American Prospect Spring: 35-42

Putnam, R.D., 1995, 'Tuning In, Tuning Out: The Strange Disappearance of Social Capital in America', PS, 28:664-683

Scott, A. D., 1995, Institutions and Organizations, Foundations for Organizational Science, London: Sage Publications

Shanmugaratnam, N., T. Vedeld, A. Mossige, and M. Bovin, 1992, Resource Management and Pastoral Institution Building in West African Sahel, Washington: World Bank Discussion Papers no. 72

Singleton, S. and M. Taylor, 1992, 'Common Property, Collective Action and Community', Journal of Theoretical Politics 4:309-324

Turner, M. D., 1992, Life on the Margin: Fulbe Herding Practices and the Relationship Between Economy and Ecology in the Inland Niger Delta of Mali, D Phil in Energy and Resources, Berkeley: University of California

Uphoff, N., 1998, 'Community-Based Natural Resource Management: Connecting Micro and Macro Processes, and People with Their Environments', International Workshop on Community-Based Natural Resource Management, May 10-14, Washington D.C: World Bank

Vedeld, T., 1997, Village Politics: Heterogeneity, Leadership and Collective Action, Doctor Scientiarum Thesis no. 13, Dep. of Land Use Planning, Aas: Agricultural University of Norway

Vedeld, T., 1998, 'State Law Versus Village Law: Law as Exclusion Principle under Customary Tenure Regimes among the Fulani of Mali', in E. Berge and N. Chr. Stenseth (eds.) 1998: Law and Governance of Renewable Resources, Studies from Northern Europe and Africa, San Francisco: ICS Press

Wade, R., 1988, Village Republics: Economic Conditions for Collective Action in South India, Cambridge: Cambridge University Press

Wade, R., 1992, 'Common-Property Resource Management in South Indian Villages', in Bromley (ed.) 1992, Making the Commons Work, Theory, Practice and Policy, San Francisco: ICS Press

Webb, J. L. A., 1995, Desert Frontier. Ecological and Economic Change along the Western Sahel, 16001850, Madison, WI: The University of Wisconsin Press

World Bank, 1996, Towards Environmentally Sustainable Development in Sub-Saharan Africa. A World Bank Agenda, Washington D.C.: World Bank

Young, O. R., 1995, 'The Problem of Scale in Human/Environment Relationships', in Keohane, R.O. and E. Ostrom (eds) 1995, Local Commons and Global Interdependence, Heterogeneity and Cooperation in Two Domains, London: SAGE Publications 